\title{
EXPLORING NEWS EDITORS' ADVOCACY ON SOOT AND WASTE DISPOSAL IN PORT HARCOURT NIGERIA
}

\author{
Anthony Reuben Ata-Awaji \\ Department of Mass Communication, \\ Salem University, Lokoja, \\ Kogi State, Nigeria \\ +234-08124427203 \\ atawajireuben@gmail.com \\ Victor BasseyIkot-Osin \\ Department of Mass Communication, \\ University of Nigeria, Nsukka \\ 234-0708-743-0054 \\ victor.bassey@unn.edu.ng
}

\begin{abstract}
This study was undertaken to explore the practice of advocacy journalism among news editors in Port Harcourt on the menace of environmental challenges of soot and solid waste disposal in the Rivers State metropolis. News editors of 13 private radio stations in Port Harcourt formed the population for the study. The research instrument was an interview that was based on structured questions framed to extract primary data from the population. The qualitative method was adopted in analysing the data. Among other findings, the study unravelled that the practice of advocacy journalism among news editors on soot and indiscriminate dumping of solid waste is weak in Port Harcourt. More so, the study ascertained that none of the news editors adopted news commentary as an approach in the advocacy on soot and indiscriminate disposal of solid waste in Port Harcourt. Given the findings, it is recommended that news reports on soot and indiscriminate disposal of solid waste in Port Harcourt should be done regularly to strengthen the advocacy and contribute to change of attitudes of the masses toward the environment. It is also recommended, among others that news commentary should be adopted by news editors in Port Harcourt as part of the strategies to advance advocacy on soot menace and indiscriminate disposal of solid waste in that city, due to the educative, expository and detailed nature of the commentary.
\end{abstract}

\section{Keywords: Explore, Advocacy, Journalism, Editors, Environment}

\section{INTRODUCTION}

The mass media play significant roles in the societal watch in all forms. They are exercised within the responsibilities that are available to the media. One of the responsibilities of the mass media, as espoused by Harold Lasswell in 1948, is surveillance of the environment. Theorists and media critics have noted that media surveillance of the environment is tied to the news function of the mass media. However, the mass media have now adopted different approaches for societal surveillance. One of the approaches is advocacy journalism which is a subjective style of journalism that is aimed at championing a course for improvement of the fortunes of the masses and the good of the society.Through advocacy journalism, the media push for a change of situation, improvement of the situation, or maintaining a situation that is considered satisfactory. So, the mass media by doing this, move away from deadpan reporting and adopt a subjective method of journalism that is focused on fighting for a legitimate course, and not just mere reportage of societal issues. Advocacy journalism is applied in seeking justice for the less privileged people, raped victims, flood victims, widows, pensioners and different social issues that require improvement and/or sustenance for the good of the masses. 
In Port Harcourt, soot and solid wastes are grave environmental problems that are confronting the people and the government. The problems require advocacy journalism due to their negative effects on the residents of the city and the environment. The environment is the backbone of man's physical existence. Human beings rely largely on the environment for their survival. So, the basic needs of human beings: food, cloth and shelter cannot be achieved if the environment is destroyed. Also, societal development cannot be discussed without reference to the environment, therefore, it requires preservation. Given the above, Ite (2016) says environmental sustainability requires the use of environmental goods and services in such a way that their productive capacities are not reduced, nor their overall contribution to human well-being diminished (p.4).

However, human beings for whom the environment is created and whose responsibility it is to ensure the safety of the biosphere have failed to protect the environment from depletion. Accordingly, man's actions have continued to cause great damages to the environment. Worried by man's action on the environment, Usua (2016) notes that many of the resources that serve as life supports are rapidly disappearing and this has happened mostly as a result of man's attitude towards the resources themselves (p.235).

Man's negative action on the environment has been aggravated due to increase in population, industrial activities and other economic ventures. The consequences of industrial, economic activities and consumerism include an increase in solid waste. In Nigeria, federal, state and local government authorities are battling to control solid waste disposal. Rivers State is one of the states in Nigeria that has continued to battle with the consequences of solid waste on the environment.

As a result of this, beginning from the 1980s several efforts had been put in place by the Rivers State Government to address the environmental menace. In recent time, the government of Chibuike Rotimi Amaechi adopted a strategic approach in the evacuation and management of solid waste generated by residents of the state. As noted by Reuben (2018, p.106), yet, owing to the increasing challenge of rural-urban migration and overpopulation of Port Harcourt with the resultant problem of heaps of waste in the metropolis, a more strategic action plan on the state environment was established in 2013. And this is known as the Rivers State Waste Management Agency.

As people of Rivers State continued to battle with the situation amid an upswing in the population of people living in Port Harcourt, another environmental challenge surfaced in November 2016. This environmental menace is known as soot. This black substance that dots the atmosphere and later settles on cars, houses and being inhaled by the residents of the state especially those living in Eleme, Oyigbo, Obio/Akpor and Port Harcourt Local Government Areas, has been described by environmental and medical experts as dangerous, cancerous and deadly. In the words of the chairman of the committee inaugurated by the Rivers State Government to find a solution to the soot menace, Professor Precious Ede, (http://www.bbc.com, on December 9, 2019) "medical investigations reveal that black soot accounts for four per cent of lung infections in Rivers State from 2016 when the hazard started. If in the next five years nothing is done to tackle it there will be more sickness like respiratory tract infection and increase in cancer cases'.

Amid this situation, accusations and counter-accusations have continued in Rivers State. Civil Society Organizations have consistently called on the Rivers State Government, the 
Federal Government and agencies of government charged with the responsibility of tackling environmental hazards to exercise their responsibilities. However, while the federal government through its agencies always blame criminals who engage in illegal refining of crude oil (referred to as kpo fire in local parlance) for the hazard, the Rivers State Government on the other hand always accuse law-enforcement agents of being behind the situation, noting that the security agents engage in unprofessional methods in confiscating seized petroleum products from suspected criminals. The Rivers State Government had also accused the law enforcement agents of burning boats and seized petroleum products in defiance to environmental laws and practices.

As the blame game continues, the masses are looking up to societal institutions, including the mass media for solutions to the situations. Mass Media roles in championing a good course on behalf of the society have been acknowledged by experts including Okon (2013) who notes that indeed the press has a cardinal responsibility of making sense out of what goes on around us to sensitize the individual, in the society, on the goings-on in his immediate environment. The primary concern of the press, in a socio-economic system, like Nigeria, should be geared towards bringing problems to light so they can be resolved (p.7).

The press includes radio, television, newspaper, magazine and in contemporary time, the social media. Meanwhile, news editors, as framers of issues that are reported in the mass media, to a very large extent, also determine approaches to be taken in the reportage of issues. The focus of this study is, therefore, news editors of radio stations in Port Harcourt, because Ochonogor (2016) notes that "radio, with its extensive outreach, has a great potential for uniting people and helping to shape their thoughts, opinions and introducing new ideas to those living in the most remote places".

Port Harcourt has 16 radio stations. So, considering the number of radio stations in Port Harcourt, their perceived effects and availability plus the power of news editors as noted by (Beder, 2004; Fred et al, 2003), cited in Amanah and Ekwebelem (2019), that media owners or proprietors control the news selected and reported. This is done through the appointment of editors who become their voice within the newsroom, thus ensuring that journalistic independence conforms to the preferred editorial policy. These editors act as the final gatekeepers in deciding what to publish and what news stories reporters should gather. Interestingly, the power of the media is not just in its editorial policy but also in its coverage of some issues rather than others...(p.344), this study seeks to explore news editors advocacy on soot and waste disposal in port Harcourt, Nigeria.

\section{STATEMENT OF THE PROBLEM}

While driving into Port Harcourt or walking around the city, it is very common to see heaps of refuse in sacks and polythene bags littering the roadside. Solid waste is dumped on the elevated parts of roads (the median) in Port Harcourt and other parts of the state indiscriminately. Officials of Rivers State Waste Management Agency (RIWAMA) are expected to evacuate it regularly but most times it is left on the road for many days. And even when evacuated, some residue of particles of the debris is left on the median.

Such improper disposal of waste constitutes a threat not just to air quality, land, water sources, and the city's aesthetic value but also to human beings. This is because, during decomposition, it produces bad smell and serves as a breeding ground for pest that spreads diseases. 
Another environmental problem that is threatening the existence of residents of Port Harcourt is soot which effect became noticeable in November 2016. Soot poses tremendous harms to public health particularly because of its size. It can easily go into the human lungs and bloodstream and cause great damage, even to the entire body system.

The mass media, especially the broadcast media are expected to create awareness on different issues as their programmes are received by large audiences. There are sixteen radio stations in Port Harcourt. Consequently, it is expected that enlightenment on proper disposal of waste as well as actions by government and relevant agencies in tackling soot menace would have been done greatly; contributing to change of attitudes of the masses toward the environment.However, indiscriminate disposal of solid waste with soot hazard has remained unabated despite the existence of these media houses. The problem of this study is, therefore, expressed in the foregoing.

\section{RESEARCH OBJECTIVES}

The major aim of this study is to explore news editors' advocacy on soot and waste disposal in Port Harcourt, while the goal of the study, among others, revolves around the need to:

$>$ Ascertain approaches adopted by news editors of radio stations in Port Harcourt in carrying out advocacy on soot and indiscriminate disposal of solid waste in Port Harcourt,

$>$ Find out if news editors of radio stations in Port Harcourt attach seriousness to advocacy journalism on soot and indiscriminate disposal of solid waste in Port Harcourt,

$>$ Identify major obstacle confronting the news editors in their advocacy on soot and indiscriminate disposal of solid waste in Port Harcourt.

\section{RESEARCH QUESTIONS}

$>$ What approaches do news editors of radio stations in Port Harcourt adopt in carrying out advocacy on soot and indiscriminate disposal of solid waste in Port Harcourt?

$>$ Do news editors in Port Harcourt attach seriousness to advocacy journalism on soot and indiscriminate disposal of solid waste in Port Harcourt?

$>$ What is the major obstacle confronting the news editors in their advocacy on soot and indiscriminate disposal of solid waste in Port Harcourt?

\section{SIGNIFICANCE OF THE STUDY}

This study, having being undertaken following the problem posed by soot and indiscriminate disposal of solid waste in the streets of Port Harcourt and the need to unravel news editors' advocacy on this problem, will be significant to different people and organizations. Consequently, results from this study will fill the literature gap in this area and contribute to knowledge in the field of communication study. It will also be significant to the Rivers State Government, Rivers State Waste Management Agency and other environmental agencies. Researchers and students of mass communication and those in environmental sciences will equally find this study useful. 


\title{
THEORETICAL SUPPORT
}

This study is based on Yale's Persuasive Theory and Social Judgement/Involvement Theories. Yale's attitude change theory is the social psychological study of the conditions under which people are most likely to change their attitude in response to persuasive messages. It is believed that this method to persuasive communication was adopted by Carl Hovland and his associates at Yale University around the 1940s and 1950s but was later referred to as the Yale attitude change approach.

There have been hundreds, if not thousands of experimental studies that might influence comprehension, acceptance and retention of persuasive messages. Hoveland et al, cited in Asemah, et al (2016) assert that whenever any persuasive information is offered by a source that is not trusted, it tends to be discounted by the audience. As a result, immediately after exposure, there is little or no attitude change; but then, after several weeks, the source is no longer associated with the issue in the minds of the audience with positive attitude changes appear. The theory states that many factors will affect how likely a change of attitude through persuasion can be, stressing that behavioural change cannot occur without attitude change also having taken place. The three most prominent factors are the source, the messages and the audience. The Hoveland-Yale model says the content of the information is a crucial factor. So, an argument is more effective if you show both sides of the argument, but then show why your opinion is correct (Asemah et al, 2016). Ajzen (2014) corroborates Asemah et al (2016) view when he asserts that:

\begin{abstract}
the most frequently studied source factors, however, are the communicator's credibility and attractiveness. Credibility refers to the perceived expertise and trustworthiness of the communicator. In other words, does the communicator have the knowledge to provide an informed opinion on the issue in question and, if so, can he or she be trusted to present all relevant information in an unbiased fashion? As noted earlier, persuasion is generally assumed to increase with credibility. It has similarly been proposed that the amount of change is influenced by the attractiveness or likability of the source, whether attractiveness is defined in terms of physical features or psychological and behavioural characteristics (p4)
\end{abstract}

It implies that the source or the person who is presenting a message can influence its persuasiveness. This is usually referred to as source credibility. It could be stated that people are more likely to be persuaded by the words of experts than that of those who are inexperienced. Similarly, if people do not trust the source of a message they will not be persuaded by the source. Three important areas of investigation into the content of persuasive messages are message arguments (quality and quantity of arguments), evidence and fear appeals. Research demonstrates that the strength of an argument is directly related to attitude change.

It means the stronger the argument, the more the attitude change it creates and the weaker the argument, the less attitude change it creates. So, arguments that are stronger or of higher quality would be more persuasive than weaker arguments. Messages with more argument are more persuasive than those with fewer arguments. The more arguments in a message, the more likely it will seem to be true or the more likely that message will include at least, one argument that appeals to the audience. These factors probably influence persuasion.

Another theory adopted for this work is advocacy theory. According to Diri and Ezeji, (2019) advocacy communication theory argues that there should be an injection of the media and communication advocacy brand in championing certain issues in society. Media and communication advocacy is going beyond and above the routine journalism of reporting and 
writing to positioning journalists as advocates for social change through their writings-news, features, columns, editorials, documentaries, commentaries, etc. Advocacy means any action geared towards changing the policies, positions or programmes of any institution. The first step is to identify a problem in the community. One needs to understand all the aspects of the problem and find ways to help others to understand the problem fully. Then one can find ways to solve the issue (p.307). In solving environmental problems, Ukala (2010) argues that environmental communication messages should serveto educate, alert, persuade and help solve environmental problems.

From the foregoing, it can be asserted that advocacy journalism is both a philosophy and an action. A philosophy because it takes on a subjective approach in the practice of journalism, aimed at interpretation and analysis of situations, issues and policies to enhance understanding of the issues by the masses. It approaches the subjective discourse with the responsibility to the society and commitment to journalistic ethical considerations while advancing a cause or suing for a change in action. On the other hand, it is an action because it involves an implementation or adoption of well-thought-out communication strategy and approach to seeking a change of policies or improvement of a situation. This approach could also aim at suing for maintenance of a policy that has given relief to the masses but which the government or the policymakers want to change. The messages that are promoted under this genre of journalism are illustrative, interpretative, fact-based and persuasive in nature. This will lead to the actualization of the view expressed by Aigbeet al (2017) that to enjoy a clean and healthy Nigerian environment, there is an urgent need for dissemination of information, education and enlightenment of environmental issues to the public...The absence of enlightenment is the cause of the lackadaisical attitude of most Nigerians towards the environment and environmental concerns (p.43).

The above view corroborates the submission by Akporido (1997), cited in Okoro et al (2012), that:

public awareness on environmental issues will intimate man on the effects of some industrial operations on his health and the physical environment, enlighten him on various environmental laws and regulations that are available in our society and inspire a greater sense of respect for the environment. Bearing in mind that problems of environmental pollution are traced to man's activities that accumulate in bits and consequently altering his environment negatively, environmental information and awareness campaign will enlighten the people to understand the consequence of their action to avert any further degradation of the environment

Woodruff (1996), notes that "media advocacy was instrumental in the success of a campaign that pressured the alcohol industry to change how they portray women in much of their advertising".

The two theories are, therefore, relevant to this work. While Yale's attitude change theory notes the conditions under which people are most likely to change their attitude in response to persuasive messages, advocacy journalism takes it upon itself to champion the course for a change of bad policies and/or maintenance of good policy, while maintaining journalistic responsibility to the society. So, people and/or situation can be changed due to the nature of advocacy communication. 
Volume 1 Number 1 Maiden Issue

\section{LITERATURE REVIEW}

All environmental media-the atmosphere, groundwater and surface water, and soil-are vulnerable to hazardous waste contamination. Ocean pollution, soil contamination, disease, fish kills, and livestock loss are among the potential damages. The health and ecological effects can be severe and long term (Thomas et al, 2007). Other contaminants are anthropogenic, meaning caused by human activity. These include such substances as carbon monoxide from tailpipe exhausts and sulfur dioxide emissions from electricity generation. Although these types of pollutants are controllable and generally present a greater environmental risk than natural contaminants, they cannot be avoided completely without incurring the unrealistic opportunity cost of no industrial activity...Using economic, we can identify an efficient level of air quality where the associated marginal social benefits are balanced with the marginal social cost...However, the real-world complexities of government procedures, scientific uncertainty, and political pressures tend to delay or even prohibit the realization of an economic approach (p.190). Mugenda et al (2014) had noted that sudden and unexpected concentration of people in urban areas places a stream on the environment far greater than absolute numbers of people. High-density population in every small urban area means that wastes and all other aspects of pollution are also concentrated, often to such a degree that natural processes are unable to cleanse the environment of contaminants.

The above submissions are lucid demonstrations of environmental problems in the world. In Nigeria, the government and people are seriously facing environmental problems. In Port Harcourt, environmental problems are common. Major among the environmental hitches that are threatening the lives of people in Port Harcourt are soot and indiscriminate disposal of solid waste. Consequently, studies have been done on these problems in Port Harcourt and elsewhere, to find solutions to them. A few of these studies are reviewed in this work.

Obuah and Okon (2017) while highlighting the deplorable state of solid waste management across the country, in their study on "Environmental Communication Strategies of the Rivers State Waste Management Agency (RIWAMA): Implications for Sustainable Waste Management in Nigeria", noted that environmentally harmful practices seem to be commonplace phenomena in Rivers State and by extension Nigeria. Citing The United Nations Environmental Programme(UNEP) report on Ogoni land and Emeribe (2000), the duo went further to assert that the waste problem is as old as man. They added that it is dynamic and has evolved. At the centre of it all, are practices such as uncontrolled urbanization, population explosion and speedy industrialization which have generated a very high rate of the waste.

In what appears to be a corroboration of Obuah and Okon's position, Ifeoluwa (2019) conducted a study on "Harmful Effects and Management of Indiscriminate Solid Waste Disposal on Human and its Environment in Nigeria". The study established that in most parts of Nigeria like Lagos, Delta State, Oyo State and Abuja, it has been noticed that heaps of littering wastes dumps are in virtually all market areas, outskirts of the cities and even on roadsides for weeks without devising any adequate means of wastes collection either by private sector or government. The study noted that the present environmental pollution derived from solid waste littering has created a lot of health challenges to household residents around the dumping sites. On the other hand, Yakubu (2017) conducted a study on "Particle (soot) Pollution in Port Harcourt Rivers State Nigeria-Double Air Pollution Burden: Understanding and Tackling Potential Environmental Public Health Impact". Citing data from World Health Organisation (WHO), the study linked $90 \%$ of air pollution-related deaths 
occurring in low-and middle-income countries to non-communicable diseases which include cardiovascular diseases (CVDs), chronic obstructive pulmonary disease (COPD), and lung cancer.

Nwachukwu et al (2012) in their survey of a 5-year (2003-2007) epidemiological data discovered that the levels of all the criteria air pollutants in Rivers State were significantly higher than the World Health Organisation's (WHO) specification. The study noted that air pollution was associated with air-related morbidities and mortalities in the state. Among the air-related morbidity assessed, which include cerebrospinal meningitis, chronic bronchitis, measles, pertussis, pulmonary tuberculosis, pneumonia and upper respiratory tract infection, pneumonia was the most prevalent for all of the years that were studied and was responsible for the highest number of deaths in 2005.

In another study to ascertain the disease prevalence associated with industrial-related air pollution in specified Niger Delta communities, Godson et al (2010) established strong relationships between air pollutants, with morbidities, such as respiratory diseases, traumatic skin outgrowth, and child deformities. The study compared health effects in Eleme, a highly industrialized community with those observed in Ahoada East, a less industrialized community. A separate study conducted in 2010 by the duo further substantiated the health consequences of air pollution in Port Harcourt, and the prevalence of lung and skin cancers were found to be higher in Port Harcourt than in Ibadan.

Port Harcourt as an urban area plus its industrial status has continued to attract people. This has brought about an exponential population in the city. Because of this glitch in most urban areas, Kolstad (2011) asserts that to a large extent, air pollutants are at their worst in urban areas due to the concentration of people, both as sources of pollution (directly or indirectly) and as victims of the pollution. Air pollution can lead to health problems, including sickness as well as physical irritation and reduced human performance (p.9). Meanwhile, a study by Ojobor (2016) entitled "The role of communication in waste management: the ESWAMA experience" ascertained that ESWAMA, which means Enugu State Waste Management Agency uses radio more than all other communication methods. He argues that its ubiquitous nature, cheapness, as well as freedom from the problem of electricity, may account for this.

However, none of the above-cited studies and works investigates or explores the practice of advocacy journalism among news editors of radio stations in Port Harcourt on soot and indiscriminate dumping of solid waste in the street of Port Harcourt. This is the gap in the literature which this study seeks to fill. Moreover, According to Friedman (1990), cited in Batta (2013):

Interest in environmental issues among journalists began in the 1980s. In 1988 Time Magazine named the earth as the planet of the year. In 1990, Pulitzer Prize was won for reporting environmental issues. Many media of mass communication including television stations in the United States began to increase their coverage of the environment. Given this background, news directors, particularly in the United States predicted that environmental issues were the issues of the 1990s (p.256)

Despite the interest of journalists on environmental issues, Asuquoet al (1992), cited in Batta (2013) contends that "the amount of vital information that are needed to either sustain the momentum of current environment efforts or are necessary to mobilise public opinion to become aware of and identify key environmental issues are still grossly inadequate". This is why this study is necessary. 
Volume 1 Number 1 Maiden Issue

\section{METHODOLOGY}

The researchers adopted the interview as the research instrument to generate primary data from the population of the study, while a qualitative approach was used to analyse the data. The interview was done on WhatsApp to generate data from news editors who were purposively sampled. The same questions that were scripted out were asked all the news editors. Thereafter, the researchers interpreted the findings. Highlighting the importance of interview in understanding events in our immediate society and environment in general, Ihejirika and Omego (2013) notes that "an interview guide or simply interview is a data collection instrument, usually, but not always, in a face-to-face setting...Interviews can also be done through telephones or internet chats".

The population of the study were news editors of 13, out of the 16 radio stations in Port Harcourt that broadcast news programme. The reason is one of the radio stations does not broadcast news programme while two other radio stations are owned by the Rivers State Government. So the study involved only the 13 privately-owned radio stations in Port Harcourt that broadcast news programmes. However, only ten news editors participated in the study out of the 13 radio stations that were chosen.Three other news editors turned down several efforts made by the researchers to involve them in the study. This, however, shows that 77 per cent of the population participated in the study.

\section{DATA ANALYSIS}

All but one, out of the 10 news editors that participated in the study is a woman. Meanwhile, apart from two of the news editors that are holders of Higher National Diploma (HND) degree in Mass Communication, eight others have Bachelor of Arts (B.A) degree and Bachelor of Science (B.Sc) degree in Mass Communication and Linguistics and Communication Studies.

Interview question 1 for psychographic data is "As a news person have you heard about advocacy journalism? 'Responses to the question by the news editors show that all of them have heard about advocacy journalism, and have attended training on advocacy journalism. Only one of the news editors is yet to attend any training on advocacy journalism. This followed question two which is "In the course of your job have you attended any training on advocacy journalism"

Interview question 3 "In your opinion, what is advocacy journalism". The various definitions of advocacy journalism by the news editors, in summary, show that they view it as a wellintended form of journalistic writing adopted in advocating for political or social change. Therefore, all, except one of the news editors, clearly understood what advocacy journalism stands for.

Meanwhile, all the news editors considered soot and indiscriminate disposal of solid waste in the streets of Port Harcourt as serious environmental problems, and have been reporting them in the news. This followed their responses to interview question 4 which is "Have you considered soot and solid waste as environmental problems in Port Harcourt?"

In the view of one person (the only female respondent), apart from the straight news report, the issue is also treated by the radio station she works for, under special report, while six others said the issue is also treated during interactive talk show and news analysis. The remaining three news editors said it is given news analysis.However, none of the editors and by implication, the radio stations, embrace news commentary as an approach in the practice 
of advocacy on soot and indiscriminate disposal of solid waste in the streets of Port Harcourt. This followed their responses to interview question 5 which is "Apart from the straight news report, what other news treatments do you give soot and indiscriminate disposal of solid waste in Port Harcourt?"This has answered research question 1 which is "What approaches do news editors of radio stations in Port Harcourt adopt in carrying out advocacy on soot and indiscriminate disposal of solid waste in Port Harcourt.

Four, out of the ten news editors (radio stations) regularly give news report about the danger of soot and indiscriminate dumping of solid waste in the streets of Port Harcourt. This followed their responses to interview question 6 which is "Have you been reporting soot and indiscriminate disposal of solid waste in your news and how often do you do this? The news editors said they always consider critical views by environmental experts against the government and its agencies responsible for controlling soot and waste disposal, as 'hot news' that should be reported to enable government take action. However, only three, out of the ten news editors embrace this advocacy often. This followed their responses to interview question 7 which is "In reporting soot and indiscriminate disposal of solid waste, do you interview environmental experts and members of the Civil Society Organisation to air their views and do you consider views by them as 'hot news' that should be reported to enable government take action? 'The stories on soot and indiscriminate disposal of solid waste in the streets of Port Harcourt are always given headline treatment by all the news editors. This followed their responses to interview question 8 which is "Do stories on soot and indiscriminate disposal of solid waste in Port Harcourt make headline?" Therefore, responses to interview questions 6,7 and 8 have answered research question 2 which is "Do news editors in Port Harcourt attach seriousness to advocacy journalism on soot and indiscriminate disposal of solid waste in Port Harcourt?"

In the meantime, the news editors said despite their advocacy journalism on soot and indiscriminate disposal of solid waste in the streets of Port Harcourt they have never been threatened by the government or its agencies, stressing that they would continue with the advocacy.This followed their responses to interview question 9 which is "Have you been threatened by government or its agents as a result of your advocacy journalism on soot and indiscriminate disposal of solid waste in Port Harcourt?". This has answered research question 3 which is "What is the major obstacle confronting the news editors in their advocacy on soot and indiscriminate disposal of solid waste in Port Harcourt?

\section{DISCUSSION OF FINDINGS}

From the data analysis, it means that in Port Harcourt, news editors, who in most cases are the Heads of News Department of the radio stations, are aware of advocacy journalism and have undergone training on it. However, one of the editors has not had any training on advocacy journalism. Due to the danger that is caused on daily basis by soot and indiscriminate disposal of solid waste in the streets of Port Harcourt, various approaches have been considered by the news editors to fight the environmental hazards. The approaches include: straight news, news analysis and interactive talk show. More so, the issues are reported and given headline treatment. It means that the news editors adopted different approaches in treating the soot menace and indiscriminate disposal of solid waste in Port Harcourt. 
Meanwhile, none of the news editors considers news commentary critical in the advocacy on soot and indiscriminate disposal of solid waste in Port Harcourt. This would negatively affect the advocacy drive because news commentary is like the editorial that is written in the newspapers. It is detailed and educative. Through news commentary, issues are interpreted to put them in proper perspective and to give the audiences a better understanding of the issues. Though written by one person among members of the editorial team, which reflects the views of one person; it serves as an aide that helps in understanding complex societal issues that are reported through straight news. The non-inclusion of news commentary, therefore, by the news editors in their advocacy on soot and indiscriminate disposal of waste in Port Harcourt, will weaken their campaign for a healthy environment. This is because, for advocacy that requires the change of attitude of a people to be successful, it should be persuasive and enlightening.

The finding that only four, out of the ten news editors regularly give reports about the dangers of soot and indiscriminate dumping of solid waste to people's lives is an indication that the advocacy by news editors in Port Harcourt on the environmental problems is weak. It means that only forty per cent of the news editors consider soot and indiscriminate dumping of solid waste in Port Harcourt as environmental problems. Given this, the fight against these environmental problems will be weak because Pershuck and Wilbur (1991), cited in Okon (2013) note that the key to a successful media campaignis to have the same message conveyed through multiple channels. Okon (2013), while analysing the assertion, maintains that "the imputation, therefore, is that advocacy does not provide a platform for lone rangers. A lone voice will inadvertently be drowned. Advocacy campaigns must be pervasive and collaborative - different channels must be used at the same time and in the same context'. Furthermore, it is only when issues are reported regularly that they become the societal agenda.

Interestingly, none of the editors has been threatened by the government or its agents as a result of their advocacy journalism. This is in pursuit of environmental friendly attitude by the masses. It means, therefore, that advocacy journalism on these environmental problems has no obstacle.

\section{CONCLUSION}

From the data analysis and discussion of findings, it shows that advocacy journalism by news editors on soot and indiscriminate dumping of solid waste in Port Harcourt is weak. This conclusion is drawn from the finding that sixty per cent of the news editors seldom give reportage on soot and indiscriminate dumping of solid waste in Port Harcourt. Moreso, the failure of the news editors to consider news commentary as a critical approach in their advocacy for a better and healthy environment, has weakened the campaign. It also shows that the news editors do not attach seriousness to the advocacy on soot andindiscriminate disposal of solid waste in the streets of Port Harcourt. Straight news, news analysis and interactive talk show that are adopted by the news editors are not enough in the enlightening process of the masses. This is why Usua (2016) maintains that the way to go about this is sustained public enlightenment and advocacy, which calls for deep concern and continued sharing of information on the part of the communicators and advocates about the practice and its implication on humans. Sustained enlightenment and advocacy entails not only deliberately designing messages that aim at persuading people to take specific actions to reduce greenhouse emissions, but also adopting different communication approaches and media to effectively reach all segments of society...(p.250). On the other hand, the revelation 
that the news editors are not threatened in their advocacy on soot menace and indiscriminate disposal of solid waste in Port Harcourt gives hope that advocacy journalism on these two environmental challenges can receive a boost in that city.Despite this, to ensure effective advocacy journalism, the assertion by Fisher (20111), cited in Omoshue et al (2016) that 'enforcement of standards is very important since man is known to be more interested in doing what is wrong than what is right. He argues further that the combination of both the media and law enforcement would yield better result', should be adhered to.

\section{RECOMMENDATIONS}

Given the findings of this work, the following recommendations are made:

$>$ Reports on soot and indiscriminate disposal of solid waste in Port Harcourt should be done regularly. The sustainability of the advocacy will tell the masses the seriousness of the issues and make them think about the issue which is capable of making them have good or better attitudes toward the environment, depending on other societal factors.

$>$ News commentary should be adopted by news editors in Port Harcourt as part of the strategies to advance advocacy journalism in that city, with the ultimate goal of achieving a clean and healthy environment.If and when embraced, it would help a great deal in driving the advocacy on soot and indiscriminate dumping of solid waste in Port Harcourt, due to the educative, expository and detailed nature of the commentary.

$>$ Editors and by extension the various radio stations in Port Harcourt should close ranks in the approaches adopted for the advocacy on soot and indiscriminate disposal of solid waste in Port Harcourt. The collaborative effort will give strength to the campaign and determine the perception of the masses about it.

\section{REFERENCES}

Aigbe, I.A \&Omo, E.E (2017). Re-factors militating against enforcement of environmental laws in Nigeria. In Addo, S.T (Ed) International journal of humanities and social science, Vol 4 (4) (pp. 32-49).

Ajzen, I (2014). Persuasive communication theory in social psychology: a historical perspective.

Amanah, P \& Ekwebelem, L. (2019). Worship places and moral decadence in society: any place for the media. In Nsereka, B (Ed) Critical media discourse readings in communication study controversies (pp.327-351).LSB Media Limited.

Asemah, E.S., Nwammuo, A.N., Uwaoma. O.A.(2016). Theories and Models of Communication. Jos University Press.

Batta, H. (2013). Coverage of environmental issues in the Nigerian print press. In Wilson, D and Batta, H (Eds) Science, health and environmental communication (pp.255-276). Ibadan University Press. 
Diri, C. T and Ezeji, A. (2019) The imperative of advocacy communication and media in tackling indigene-settler relationships in Nigeria's Plateau State. In Gambo, D and Batta, H (Eds) Communication, migration and social inclusion in Nigeria. (pp. 305114). African Council for Communication Education (ACCE, Nigeria).

Fisher, C (2016). The advocacy continuum:Towards a theory ofadvocacy in journalism. Journalism Vol. 17(6) (pp.711-726). SAGE.

Ihejirika, W.C \&Omego, C. (2013) Research methods in linguistics and communication studies (Second Impression). University of Port-Harcourt Press Ltd.

Ite, U.E. (2016). Perspectives on self-reliance and sustainable development in Nigeria, lead paper for 2nd National Conference of Academic Staff Union of Polytechnics (ASUP), KenuleBinsonSaroWiwa Polytechnic, Bori, Rivers State.

Kolstad, C.D (2011). Intermediate environmental economics.Oxford University Press, Inc.

Mugenda, O.M. \&Muriuki, J.N. (2014). Urbanization challenges in poor slum areas of Nairobi and the role of sustainability science in seeking practical solution, in Ologunorisa, T (Ed) African journal of sustainable development, Vol 4 (3) (pp.169181).

Nwachukwu, A.N., Chukwuocha, E.O \& Igbudu, O. A (2012). Survey on the effects of air pollution on diseases of the people of Rivers State, Nigeria. Afr. J. Environ. Sci. Technol. Vol 6 (pp. 371-379).

Obuah, P.F. and Okon, G.B. (2017). Environmental communication strategies of the Rivers State Waste Management Agency (RIWAMA): implications for sustainable waste management in Nigeria. International journal of development and sustainability, Vol.6 (11) (pp.1541-1558).

Ochonogor, C.I (2016). Mitigating the effects of oil pollution in the Niger Delta through communication campaigns. In Soola, E.O, Udoudo, A.J \&Ochonogor, C.I (Eds) Issues and trends in environmental communication. Kraft Books Limited (pp.253275).

Ojobor, I.J. (2016). The role of communication in waste management: the ESWAMA experience. In Soola, E.O, Udoudo, A.J \&Ochonogor, C.I (Eds) Issues and trends in environmental communication. Kraft Books Limited (pp.304-347).

Okon, G. B (2013). The Niger Delta crisis and advocacy for peace by the Nigerianpress: a content analysis of three Nigerian newspapers. In www.iiste.org, vol 14 (pp.7-17).

Okoro, N\& Nnaji, G. O (2012). Press coverage of environmental pollution in the Niger Delta region of Nigeria. A content analysis of the Guardian, Vanguard, Daily Sun and This Day newspapers. In Journal of humanities and social science, Volume 3, (2)(pp-3446). 
Omoshue, J.O \&Asadu, C.A. (2016). Maintaining a healthy and sustainable environment through communication campaigns. In Soola, E.O, Udoudo, A.J \&Ochonogor, C.I (Eds) Issues and trends in environmental communication. Kraft Books Limited (pp.42-61).

Reuben, A.A. (2019).Public perception of communication strategies of waste management agencies in Rivers and Abia States. In Okoro, N (Ed) International Journal of Communication: An Interdisciplinary Journal of Communication Studies, ( 24) (pp.106-119).

Thomas, M.T \& Callan, S.J (2007). Environmental economics application, policy, and theory. Thomson South-Western.

Ukala, E.(2010). Gas flaring in Nigeria's Niger Delta: Failed promises and reviving community voices. Washington and Lee journal of energy, climate and the environment. 2(1). (pp.98-126).

Usua, N.J (2016). Reducing greenhouse emission through public enlightenment and advocacy. In Soola, E.O, Udoudo, A.J \&Ochonogor, C.I (Eds) Issues and trends in environmental communication. Kraft Books Limited (pp.235-251).

Woodruff, K. (1996). Alcohol advertising and violence against women: a media advocacy case study'. Health education and behaviour, Vol 23 (3)(pp.330- 345).

Yakubu, O. H. (2017) Particle (soot) pollution in Port-Harcourt Rivers State, Nigeria, -double air pollution burden? understanding and tackling potential environmental public health Impacts. International Journal of Environmental Research). 